\title{
Determinants of Mango Market Supply and Outlet Choice: The Case of Gambella and Itang Special Districts of Gambella Regional State, Ethiopia
}

\section{Temesgen Kabeta and Jemberu Alemu*}

Gambella University, College of Agriculture and Natural Resources, Ethiopia

*Corresponding Author: Jemberu Alemu, Gambella University, College of Agriculture and Natural Resources, Ethiopia.

Received: October 23, 2019; Published: November 13, 2019

DOI: 10.31080/ASAG.2019.03.0719

\begin{abstract}
The study was conducted in Gambella and Itang Special districts of Gambella Regional state of Ethiopia on Determinants of mango market supply and channel choice with specific objectives of analyzing determinants of mango market outlet choice and volume of mango market supply in study areas. Both qualitative and quantitative types of data were collected from both primary and secondary sources of data through semi- structured questionnaire. Multistage sampling technique was employed to draw sample populations (195 respondents) from 4192mango producers and by using convenience sampling 10 wholesalers, 12 local collectors, 30 retailers and 3 processors and 20 consumers was interviewed. Both descriptive and econometric models were employed to analyze data's. Multiple linear regression result indicated that age of household, quantity of mango produced, livestock holding unit, non-farm income, and distance from the market center were influenced quantity of mango supplied to market at 10\%, 1\%, 10\%, and 5\% significance level, respectively. The likelihood of choosing local collector was influenced by volume of mango supplied positively, quantity of mango produced negatively, non-farm income positively, and distance from the market center positively at $10 \%, 5 \%, 1 \%$ and $1 \%$ significance level, respectively. The likelihood of choosing wholesaler market outlet was influenced by household size positively, quantity of mango supplied positively, non-farm income positively, and distance from the market center negatively at $10 \%, 1 \%, 1 \%$, and 1\% significance level, respectively. Recommendations drawn from the study findings include the need to improve the input supply system, training farmers, increasing quality of market information, providing orientation on how to use appropriate market outlet to minimize cost and earn maximum margin and profit, improving productivity and volume sales of teff, constructing infrastructure, providing extension and credit services and strengthening supportive institutions, respectively.
\end{abstract}

Keywords: Mango; Market Outlet; Market Supply; Multiple Linear Regressions; Multivariate Probit

\section{Introduction}

In Ethiopia fruit crops grown by the private peasant holders cover only a small token area and production. The number of holders practicing fruit farming is much less than that of grains or cereals. About 107,890.60 hectares of land is under fruit crops in Ethiopia. Bananas contributed about $58.59 \%$ of the fruit crop area followed by avocadoes that contributed $16.53 \%$ of the area. More than 7,923,665.02 quintals of fruits was produced in the country. Bananas, Mangoes Avocados, Papayas, and Oranges took up $67.94 \%, 13.21 \%, 8.20 \%, 6.36 \%$ and $2.61 \%$ of the fruit production, respectively. Mango produced by 1,857,387.00 smallholder producer on $15,373.04$ hectares of land with $14.72 \%$ of land were allocated and 1,049,807.79 quintals of mango were produced and contributed by $13.5 \%$ to fruit production with productivity of 68.29 quintals in the country. Mango produced all over the region of Ethiopia. From regions of Ethiopia, in Gambella region mango produced by 6,267 smallholder farmers on 52.88 hectares of land. So, the aim of this study is to conduct determinants of volume of mango market supply and farmers channel choice [1].

Bezabih [2] indicated that, agriculture continues to face a number of constraints and obstacles in Ethiopia. The major ones are adverse climatic conditions; lack of appropriate land use system resulting in soil and other natural resources degradation; limited use of improved agricultural technologies; the predominance of subsistence agriculture and lack and/or absence of business oriented agricultural production system; limited or no access to market facilities resulting in low participation of the smallholder farmers in value chain. In comparison to this, the study by Jifara and Amsalu [3] indicates that, agricultural marketing is a very important factor in economic development and lack of a well market and marketing system severely hinders developing countries. The study area is known by production of mango mainly for market and family consumption and supply of mango in the study area is subjected to seasonal variation where surplus supply at harvest is the main feature. However, market aspects of mango were not studied in those districts and undertaken in other areas by different authors, did not address market aspects of mango in study area.

Most of the previous researchers on the same topic and at different study area has used multinomial logit model to examine factors affecting market outlet choice of the crop which is inefficient i.e. Multivariate Probit model is appropriate because farmers have more than one outlet options. To examine factors affecting market 
supply previous researchers used OLS without testing the possible endogeneity problem 2SLS method and missed to use [4]. Yet there is no such study which tries to look into the whole spectrum of mango in the district and encouraged the researcher undertaking of mango market in these district is essential.

Since mango is economically and socially crucial crop in Itang and Gambella districts, this study is designed to address the prevailing information gap on proper understanding of demographic, socioeconomic and institutional determinants of mango market supply and market outlet choice. Therefore this study identifies factors affecting mango market supply and mango market outlet choices of smallholder farmers and readdresses the knowledge gap. So the objectives of the study were designed to analyze determinants of mango market supply and market outlet choice in study areas.

\section{Methods}

\section{Description of study area}

The study was conducted in Abobo and Itang special districts Gambella Regional state, Ethiopia. Gambella region is one of nine regional states of Ethiopia found at the south western region of the country and bounded by South Sudan to the west, Kellem Wollega Zone, Ilu Ababor Zone and Sheka Zone.

\section{Data types, sources and methods of data collection}

Data types and sources

For this study both qualitative and quantitative data were collected from primary and secondary sources. Primary data sources were smallholder mango producer farmers randomly interviewed and from purposively selected traders and consumers. Secondary data sources are districts agriculture and rural development offices, primary cooperatives, district trade and industry offices, data taken from CSA, published and unpublished materials either from internet and bulletins.

\section{Methods of data collection}

- Primary data: The data was collected formally by the method of individual interview using pre tested structured questionnaire, while data from focus group discussion and key informant interview was collected by using checklists. Before distributing the pre tested questionnaire for enumerators, the investigators were train enumerators on how to collect relevant data from concerned respondents.

- Secondary Data: By using checklists data was gathered from published and unpublished materials, district agriculture and rural development offices, farmers' organizations, input suppliers, marketing agencies, primary cooperatives, districts industry and trade office.

Sampling Procedure and Sample Size

Farmers sampling

Multistage sampling technique was employed to select sample districts, kebeles and producers. Two districts were selected purposively by potentiality of their mango production. At first stage two districts (Gambella and Itang) were selected purposively. At second stages using random sampling technique six kebeles were selected (three kebeles from each district). At the third stage from 4192 mango producers (2240 from Itang Special district and 1952 from Gambella Zuria district) 195 (102 from Itang and 93 from Gambella) [5] sample farmers was selected by using (PPS) and Yemane [6] formula.

$$
\left.n=\frac{N}{1+N(e)^{2}} 1\right)
$$

Where, $\mathrm{n}=$ sample size, $\mathrm{N}=$ Number of household heads of mango producer and e = level of precision assumed 7\%. Accordingly, the required sample size at $93 \%$ confidence level with level of precision equal to $7 \%$ was used to obtain a sample size required which represent a true population. Traders for this study were selected using convenience sampling technique. Around 10 wholesalers, 12 local collectectors, 30 retailers and 3 processors and 20 consumers were interviewed.

\section{Methods of data analysis}

From STATA13 software, Descriptive statistics, inferential statistics and econometric analysis were used to analyze the data collected from all respondents involved in mango production and marketing in study area.

\section{Descriptive statistics}

Descriptive statistics such as mean, frequencies and percentages in the process of examining and describing demographic outputs and marketing functions was applied.

\section{Econometric models}

Econometric models was employed to analyze the impact of one unit changes in explanatory variable on dependent variables i.e. factors affecting supply of mango to the market, factors determining choices of market outlet decision of farmer in study area.

\section{Factors affecting mango market supply}

Multiple linear regressions were used to analyze determinants of mango market supply since all mango producer farmers are mango market participants. Sultan [7] has used to analyze factors affecting wheat market supply in Sinana district of Bale zone. The study conducted by Mohammed [8] applied multiple linear regressions to quantify determinants of market supply of teff and wheat in Halaba Special Woreda, Southern Ethiopia. In addition to the above study, Azeb., et al. [9] analyzed factors affecting teff and wheat market supply in Dendi District, West Shoa Zone, Ethiopia using Multiple linear regression models.

In estimating factors that affect household's levels of market participation, OLS model is applicable if and only if all the households participate in the marketing of the commodity of interest. If participation of all households in marketing of the commodity is not expected, using OLS model by excluding non-participants from the analysis introduces selectivity bias to the model. Tobit, Double Hurdle and Heckman two stage procedures have been suggested to 
overcome such problems. If only probability of selling is to be analyzed, Probit and logit models can adequately address the issue [4]. Almost all farmers produce for selling purpose because of its price is more than twice expensive than other cereal crops such as maize and barley's. Multiple linear regression model is specified as: Multiple regression models is model in which the dependent variable, or regressand, Y depends on two or more explanatory variables, or Regressor.

$Y i=\beta_{0}+\beta_{1} X_{1}+\beta_{2} X_{2}+\beta_{3} X_{3}+\beta_{4} X_{4}+\cdots \beta_{k X_{k}}+U i$

$Y_{i}$ is quantity of mango supplied to the market while $\beta_{0}, \beta_{1}, \beta_{2}$, $\beta_{3}$, and $\beta_{4}$ are vector of parameters to be estimated, $X_{1}, X_{2}, X_{3}$ and $X_{4}$ are vector of explanatory variables and $U$ are disturbance term or stochastic term. $\beta_{0}$ is the intercept term which gives the average value of $Y$ when $X_{1}, X_{2}, X_{3}$ and $X_{4}$ are zero [4].

\section{Factors affecting market outlet choice of mango producers}

The multivariate probit model takes into account the potential interdependence in market outlet choices and the possible correlation in the choice of alternative outlets. The probability of preferring of any particular market outlet is estimated conditional on the choice of any other related outlet. The multivariate probit model assumes that each subject has distinct binary responses, and a matrix of covariates that can be any mixture of discrete and continuous variables. Generally speaking, the multivariate probit model assumes that given a set of explanatory variables the multivariate response is an indicator of the event that some unobserved latent variable falls within a certain interval.

A farmer's marketing outlet choice was conceptualized using the random utility model (RUM). RUM is particularly appropriate for modeling discrete choice decisions such as between market outlets because it is an indirect utility function where an individual with specific characteristics associates an average utility level with each alternative marketing channel in a choice set. The mango producers were mapped into four marketing outlets: sales to collector, consumer, cooperative, and retailer. The mango producing farmer $\mathrm{i}$ was able to choose from a set of alternatives $(j=1,2,3$,and 4$)$ which provided a certain level of utility Uij from each alternative. This model was based on the principle that the farmer will choose the outlets that will maximize his/her utility. The farmer will make a comparison on marginal benefit and cost based on the utility that will be gained by selling to a combination of market outlets which will maximize its utility). However, it is not possible to directly observe the utilities but the choice made by the farmer revealed which marketing outlet provides the greater utility [10]. Hence, the utility was decomposed into deterministic (Vij) and random ( $\varepsilon i j)$ part:

$\mathrm{Uij}=\mathrm{Vij}+\varepsilon i j(3)$

Since it was not possible to observe iij and predict exactly the choice of marketing outlet, the probability of any particular outlet choice was used in which a farmer selected a marketing outlet $j=1$ if:

Uik $>$ ui $\forall j \neq k(4)$
Where Uik represents a random utility associated with the market channel $\mathrm{j}=\mathrm{k}$, Vij represents an index function denoting the decision-makers' average utility associated with this alternative, and عij represents the random error. As mango producers more likely choose two or more than two types of outlets simultaneously in the study area, assuming the selection of different marketing outlets, as well as their simultaneous use, depends on producers' willingness to maximize their profit and is conditional to socioeconomic, institutional, production, and market-related factors [10-12]. Following the literature, the researchers concluded that a producers' decision to sell in an advantageous market derives from the maximization of profit he or she expects to gain from these markets.

The household decision of whether or not to choose is considered under the general frame work of utility or profit maximization $[13,14]$. It is assumed that given producer $\mathrm{i}$ in making a decision considering not exclusive alternatives that constituted the choice set Kth of mango marketing outlets, the choice sets may differ according to the decision maker. Consider the ith farm household (i $=1,2 \ldots . . . \mathrm{N}$ ) facing a decision problem on whether or not to choose available market outlets. Let Uk represent the benefit of farmer to choose the Kth market outlet: where $\mathrm{K}$ denotes the choice of retailers'(Y1) cooperatives (Y2), collectors (Y3), and consumers (Y4) and wholesalers( Y5). The farmer decides to choose the Kth market outlets if $\mathrm{Y}^{*} \mathrm{ik}=\mathrm{U}^{*} \mathrm{k}-\mathrm{U} 0>0$. The net benefit $\left[\mathrm{Y} \rrbracket^{\wedge * i \mathrm{k}) \text { that }}\right.$ the farmer derives from choosing a market outlet is a latent variable determined by observed explanatory variable (Xi) and the error term ( $\varepsilon i)$ :

$$
Y^{\wedge} * i k=X^{\wedge \prime} \beta_{-} k+\varepsilon_{-} i(k=Y 1, Y 2, Y 3, Y 4 \text { and } Y 5)(5)
$$

The econometric approach for the study is by using the indicator function; the unobserved preferences in above equation translate into the observed binary outcome equation for each choice as follows:

$\mathrm{Y}_{\mathrm{ik}}=\left\{\begin{array}{c}1 \text { if } \mathrm{Y}^{*} \mathrm{ik}>0 \\ 0 \text { otherwise }\end{array}(\mathrm{k}=\mathrm{Y} 1, \mathrm{Y} 2, \mathrm{Y} 3, \mathrm{Y} 4\right.$ and $\mathrm{Y} 5(6)$

In case of multivariate model, where the choice of many market outlets is possible, the error terms jointly follow a multivariate normal distribution (MVN) with zero conditional mean and variance normalized to unity (for identification of the parameters) where $\left(\mu \_x 1, \mu \_x 2 \mu \_(x 3,) \mu_{-}(x 4,) \mu_{-} x 5\right) M V N \sim(0, \Omega)$ and the covariance matrix $\Omega$ is given by:

$\Omega=\left\{\begin{array}{ccccc}1 & \rho \times 1 \times 2 & \rho \times 1 \times 3 & \rho \times 1 \times 4 & \rho \times 1 \times 5 \\ \rho \times 2 \times 1 & 1 & \rho \times 2 \times 3 & \rho \times 2 \times 4 & \rho \times 2 \times 5 \\ \rho \times 3 \times 1 & \rho \times 3 \times 2 & 1 & \rho \times 3 \times 4 & \rho \times 3 \times 5(7) \\ \rho \times 4 \times 1 & \rho \times 4 \times 2 & \rho \times 4 \times 3 & 1 & \rho \times 4 \times 5 \\ \rho \times 5 \times 1 & \rho \times 5 \times 2 & \rho \times 5 \times 3 & \rho \times 5 \times 4 & 1\end{array}\right.$

Of particular interest are the off-diagonal elements in the covariance matrix, which represent the unobserved correlation between the stochastic components of the different types of outlets. This assumption means the above equation generates a MVP model that jointly represents s decision to choice particular market outlet. This specification with non-zero off-diagonal elements allows for correlation across error terms of several latent equations, which 
represents unobserved characteristics that affect the choice of alternative outlets. Following the formula used by Cappellarri and Jenkins [15], the log-likelihood function associated with a sample outcome is then given by:

$$
\ln L=\Sigma_{-}(i=1)^{\wedge} N=\omega_{-} i l n \emptyset(\mu i, \Omega)(8)
$$

Where $\omega$ is an optional weight for observation $\mathrm{i}$ and $\Phi \mathrm{i}$ is the multivariate standard normal distribution with arguments $\mu \mathrm{i}$ and $\Omega$, where $\mu \mathrm{i}$ can be denoted as:

$\mu \_i=\left(k \_i 1 \beta \_1 X \_1 i, k \_i 2 \beta \_2 i X \_2 i, k \_i 3 \beta \_3 i x \_(3 i)\right.$ while $\Omega i k=1$ for $j=k$ and

$\Omega j \mathrm{k}=\mathrm{k} \_\mathrm{ijk} \_\mathrm{ik} \rho$ _jk for $\mathrm{j} \neq \mathrm{k}, \mathrm{k}=1,2,3,4 \ldots$ with $\mathrm{k}_{-} \mathrm{ik}=2 \mathrm{y} \_\mathrm{ik}-1$ (9)

\section{Results and Discussion}

Demographic and socio-economic characteristics of respondents

As discussed in hypothesis before some demographic, socio economic and institutional variables were hypothesized to influence dependent variable either negatively or positively were age of respondents, household size in adult equivalent, education years of respondents attended in years of schooling, farming experience in years of starting mango production, quantity of mango produced, productivity of mango per tree, quantity of mango supplied in quintals, price of mango at each outlet choice, total livestock holdings in TLU, nonfarm income in birr, number of extension contact, distance from the nearest market center in kilometers, sex of respondents, using credit relating to mango production and marketing, access to market information, having transport facility used for study.

So the study result showed that there was a significant difference between districts in education years attended by respondents and it indicates that due to Gambella district is found near to Gambella Town (access to schools), there was significant difference in years of schooling at $1 \%$ significance level (Table 1). As well as quantity of mango supplied was also statistically significant difference at $1 \%$ significance level in Itang special district and Gambella district (Table 1), and the study result further shows that because of Gambella district is near to Gambella Town (Regional Town market) or near to market demand for mango is more marketable than in Itang Special district. There was also a significant difference in price of mango at $1 \%$ significance level in Itang and Gambella district respectively and this result further indicates that price of mango at Gambella district is fairer than at Itang special district because of its nearness to the regional town. And also Total livestock holding was also statistically significant at $1 \%$ significance level in Itang special district because there were large livestock holdings in Itang district than Gambella district.

There were also significance difference in access to market information at $1 \%$ significance level and it further shows that those respondents (Table 1).

\section{Determinants of mango market supply}

The multiple linear regression result showed that the model fitted the data because of Prob $>\mathrm{F}$ is statistically significant at $1 \%$ (0.001) and Goodness of fit of the model is $68.5 \%$ which shows the

\begin{tabular}{|c|c|c|c|c|}
\hline \multicolumn{2}{|c|}{ Continuous Variables } & t-value & \multicolumn{2}{|c|}{ Mean difference } \\
\hline \multicolumn{2}{|c|}{$\begin{array}{l}\text { Age of household head in } \\
\text { years }\end{array}$} & 1.41 & \multicolumn{2}{|c|}{3.88} \\
\hline \multicolumn{2}{|c|}{$\begin{array}{l}\text { Education of household in } \\
\text { years of schooling }\end{array}$} & $6.967^{* * *}$ & \multicolumn{2}{|c|}{5.86} \\
\hline \multicolumn{2}{|c|}{$\begin{array}{c}\text { Household Size in adult } \\
\text { equivalent }\end{array}$} & 0.801 & \multicolumn{2}{|c|}{38.32} \\
\hline \multicolumn{2}{|c|}{$\begin{array}{l}\text { Farming experience in years } \\
\text { of starting mango production }\end{array}$} & 1.286 & \multicolumn{2}{|c|}{23.48} \\
\hline \multicolumn{2}{|c|}{$\begin{array}{l}\text { Quantity of mango produced } \\
\text { in quintal }\end{array}$} & 1.577 & \multicolumn{2}{|c|}{4.77} \\
\hline \multicolumn{2}{|c|}{$\begin{array}{l}\text { Productivity of mango per } \\
\text { tree }\end{array}$} & 1.102 & \multicolumn{2}{|c|}{6.097} \\
\hline \multicolumn{2}{|c|}{$\begin{array}{l}\text { Quantity of mango supplied } \\
\text { in quintals }\end{array}$} & $10.145^{* * *}$ & \multicolumn{2}{|c|}{4.13} \\
\hline \multicolumn{2}{|c|}{$\begin{array}{c}\text { Number of mango trees } \\
\text { owned }\end{array}$} & 1.22 & \multicolumn{2}{|c|}{8.11} \\
\hline \multicolumn{2}{|c|}{ Price of mango per quintal } & $36.29^{* * *}$ & \multicolumn{2}{|c|}{394.19} \\
\hline \multicolumn{2}{|c|}{$\begin{array}{l}\text { Total livestock holdings in } \\
\text { Tropical livestock unit }\end{array}$} & $-8.71^{* * *}$ & \multicolumn{2}{|c|}{4.79} \\
\hline \multicolumn{2}{|c|}{ Non-farm income } & -7.269 & \multicolumn{2}{|c|}{3066.63} \\
\hline \multirow{2}{*}{\multicolumn{2}{|c|}{$\begin{array}{l}\text { Number of extension contacts } \\
\text { monthly }\end{array}$}} & 10.408 & \multicolumn{2}{|c|}{3.88} \\
\hline & & 2.6 & \multicolumn{2}{|c|}{6.9} \\
\hline $\begin{array}{l}\text { Discrete } \\
\text { variables }\end{array}$ & Response & $\begin{array}{c}\text { Itang } \\
\text { Special } \\
\text { district }\end{array}$ & Gambella & $\chi^{2}$ \\
\hline \multirow[t]{2}{*}{ Credit using } & Credit users & 15 & 22 & \multirow{2}{*}{0.101} \\
\hline & Not credit user & 88 & 69 & \\
\hline \multirow{2}{*}{$\begin{array}{c}\text { Sex of } \\
\text { respondents }\end{array}$} & Male & 72 & 66 & \multirow{2}{*}{0.875} \\
\hline & Female & 31 & 26 & \\
\hline \multirow{2}{*}{$\begin{array}{l}\text { Women } \\
\text { empower- } \\
\text { ment }\end{array}$} & Empowered & 39 & 32 & \multirow[b]{2}{*}{0.383} \\
\hline & Not empowered & 64 & 60 & \\
\hline \multirow{2}{*}{$\begin{array}{l}\text { Access to } \\
\text { market infor- } \\
\text { mation }\end{array}$} & $\begin{array}{l}\text { Access to mar- } \\
\text { ket information }\end{array}$ & 28 & 69 & \\
\hline & $\begin{array}{l}\text { Not access to } \\
\text { market } \\
\text { information }\end{array}$ & 75 & 23 & $23.21 * * *$ \\
\hline $\begin{array}{l}\text { Ownership } \\
\text { of transport }\end{array}$ & $\begin{array}{l}\text { Have transport } \\
\text { facility }\end{array}$ & 27 & 24 & \\
\hline facility & $\begin{array}{l}\text { Haven't trans- } \\
\text { port facility }\end{array}$ & 76 & 68 & 0.557 \\
\hline
\end{tabular}

Table 1: Description of continuous variables (t-test).

Source: Own data computation (2019)

included explanatory variables explained the variation in dependent variable by $68.5 \%$ since $31.5 \%$ of the variation was explained by error or disturbance term. Also heteroscedasticity problem was detected by rerunning the data with robust statistics as well as no serious multicollinearity problem since vif (variance inflation factors for continuous variable is 1.15) and CC (contingency coefficient for discrete variable is $32.6 \%$ ) [4]. The study result indicated that age of household, quantity of mango produced, livestock holding unit, nonfarm income, access to market information and distance from the market center were influenced quantity of mango supplied to the market at $10 \%, 1 \%, 10 \%, 10 \%$, and $5 \%$ significance level, respectively (Table 2). 


\section{Age of household head}

As hypothesized it influenced quantity of mango supplied to the market positively at statitistically $10 \%$ siginificance level. This positivel coefficient further indicates that as the age of the household increases by 1 year, the amount of mango supplied to the market increases by 0.041 quintal. It is also raised during key informant interview and focus group discussion and raised as almost all of mango existing in study area were controlled and owned by elder peoples than younger household because of existing mangos in study areas were old age (estimated to 15 up to 40 years old) (Table 2).

\section{Quantity of mango produced}

As hypothesized before it positively influenced quantity of mango supplied to the market at statistically $1 \%$ significant level. This positive coefficient shows that as quantity of mango produced increases by 1 quintal, the quantity of mango supplied to the market increases by 0.143 quintals. And also it further shows that those farmers produces large quantity of mango produce can supply more mangos for the market than those produces mango in small amount (Table 2). This result is in line with findings of [16] which indicated quantity produced influenced quantity supply positively at $1 \%$ significance level.

\section{Livestock Holding Unit}

Was found negatively influenced quantity of mango supplied to the market at $10 \%$ statistically significance level. This negative coefficient shows that as the livestock holding of the producer increases by 1 TLU, the quantity of mango supplied to the market decreases by 0.136 quintals (Table 2).

\section{Non-farm income}

As hypothesized it negatively influenced quantity of mango supplied to the market negatively at $10 \%$ statistically significant level. This negative coefficient further indicates that as the non-farm income increases by 1 birr, quantity of mango supplied to the market decreases by 0.0001 quintals (Table 2).

\section{Distance from the nearest market center}

As hypothesized it negatively influenced quantity of mango supplied to the market negatively at 5\% significance level. This negative coefficient further indicates that as the distance of the market from farm gate increases by $1 \mathrm{~km}$, the quantity of mango supplied to the market decreases by 0.109 quintal (Table 2). It also raised during key informant and focus group discussion as a major problem hindering mango market supply in study area.

\section{Determinants of mango market channel choice}

Multivariate Probit model was employed to analyze factors affecting farmer's market channel choice since dependent variable is multi option categorical dependent variable. This means farmers/ producers have more than one option or the probability of using all outlets simultaneously to earn average market price. The model fits the data reasonably because of Wald test (Wald chi2 (48) = $78.81, p=0.0003$ ) is significant at $1 \%$ level, which indicates that the subset of coefficients of the model is jointly significant and that the explanatory power of the factors included in the model is satisfac-

\begin{tabular}{|l|c|c|c|}
\hline Volume of Mango supplied & Coefficient & $\begin{array}{c}\text { Robust } \\
\text { Std. Err. }\end{array}$ & P>t \\
\hline Constant & -1.590 & 1.596 & 0.320 \\
\hline Age of household head & .041 & .022 & 0.070 \\
\hline Year of schooling attended & .016 & .071 & 0.827 \\
\hline Household size & -.034 & .090 & 0.705 \\
\hline $\begin{array}{l}\text { Farming experience in } \\
\text { mango production }\end{array}$ & .016 & .023 & 0.473 \\
\hline Quantity of mango produced & .143 & .073 & 0.001 \\
\hline $\begin{array}{l}\text { Number of mango tree } \\
\text { owned }\end{array}$ & .021 & .028 & 0.459 \\
\hline Livestock holding unit & -0.136 & .074 & 0.067 \\
\hline Non -farm income & 0.0001 & .0001 & 0.080 \\
\hline Number of extension contact & 0.624 & .459 & 0.175 \\
\hline Women empowerment & -0.187 & .444 & 0.675 \\
\hline Access to market information & 0.018 & .512 & 0.973 \\
\hline $\begin{array}{l}\text { Distance from the market } \\
\text { center }\end{array}$ & -0.109 & .053 & 0.043 \\
\hline Having transport facility & -0.059 & .583 & 0.919 \\
\hline
\end{tabular}

Table 2: Determinants of mango market supply.

Source: Own data computation (2019).

tory. The other is likelihood ratio test of the model is (Chi2 (6) = 16.89 , $\mathrm{Prob}>\mathrm{chi}^{2}=0.0037$ ) is statistically significant at $1 \%$ level. Indicating that the independence of the error terms (independence of market outlets choice) is rejected and there are significant joint correlations for two estimated coefficients across the equations in the model (Table 3).

The likelihood ratio test of the null hypothesis of independence between market outlet choice decisions of producers $\rho=\rho_{21}=\rho_{31}=\rho_{41}=\rho_{32}=\rho_{42}=\rho_{43}=0$, where $\rho_{21}, \rho_{31}, \rho_{41}, \rho_{32}, \rho_{42}$ and $\rho_{43}$ represents thecorrelation between wholesalers and local collector, retailer and local collector, consumer and local collector, retailer and wholesaler, consumer and wholesaler and consumer and retailers respectively. And also $\rho$ (rho) values (Likelihood ratio test of rho21 $=\operatorname{rho} 31=\operatorname{rho} 41=r h o 32=\operatorname{rho} 42=r h o 43=0$ ) are jointly equal to 0 is rejected and it indicates the goodness-of-fit of the model. Since there are differences in market outlet selection behavior among farmers, which are reflected in the likelihood ratio statistics.

According to the study result the likelihood that mango producers choose local collector, wholesaler, and retailer and consumer market outlet were $25 \%, 60.68 \%, 17.09$, and $82.97 \%$, respectively as shown in (Table 3). The joint probabilities of success and failure of the four variables also suggest that it would be unlikely for households to choose all market outlet simultaneously, for their likelihood to do so was only $3.5 \%$ while joint probability of failure were $2.22 \%$. Estimated Covariance matrix were $\rho 21$ (the correlation between the choice of local collector and wholesaler outlet was negative at $10 \%$ significance level and indicates substitution relationship between both outlets. $\rho 43$ (the correlation between consumer and retailer outlet) was positive at $1 \%$ significance level which indicates complementary relationship between consumer and retailer outlets (Table 3). 
Price of mango at each outlet (PRT)

It is continuous variable, which was price given for the commodity per quintals at different outlet. The result reveals that price of mango influenced the likelihood of choosing consumer outlet positively at $5 \%$ significance level. This positive coefficient further implies that because of consumer pays fair price than other outlets, farmer was positively associated with consumer outlets than other outlets. This finding also implies that producer prefers directly selling for consumer outlet because of farmer has bargaining power in this case and no cheating in the process of determining price, scaling weight because of price set through negotiation by depending on quality and color of mango. But findings of Addisu [17] indicated that average price of onion was associated negatively and significantly at $10 \%$ level of significance with selling onion to consumers (Table 3).

\section{Non-farm income (NONFIN)}

The survey finding implies that, those producer who earn nonfarm income were positively and significantly associated with the likelihood of choosing rural collector and wholesaler market outlet at $1 \%$ and $10 \%$ significance level, respectively, while negatively and significantly associated with the likelihood of choosing consumer outlet at 5\%, significance level. This positive and negative result showed that farmers who earns nonfarm income more likely chooses local collector to sell mango within their village and wholesaler to sell on weight rather than selling for consumers because, farmers earning non-farm income were less likely searching consumer outlet since selling for consumer takes time of the producers in order not to participate in nonfarm activities. In opposite of this findings, study by Addisu (2016) showed that availability of nonfarm income has negative and significant relation with the likelihood of choosing collector outlet at 5\% significance level (Table 3).

\section{Access to market information}

This variable negatively influenced the likelihood of choosing retailer market outlet at $10 \%$ significance level (Table 3). This negative coefficient indicates that negative association between farmers and retailer outlet because of retailer outlet charges lower price than other outlets in study area. All producers having market information concerning to price, quality, color, quantity and place of market didn't choose retailer outlet since it charges lower price for mango.

\section{Quantity of mango supplied (VMS)}

This finding reveals that, quantity of mango sold positively influenced the likelihood of choosing local collector, wholesaler and retailer market outlet at $10 \%, 1 \%$ and $1 \%$ significance level, respectively (Table 3). This implies that the larger mango quantity sold the more a farmer was likely to sell more than one outlet si-

\begin{tabular}{|c|c|c|c|c|}
\hline \multirow{2}{*}{ Variables } & Local Collector & Wholesaler & Retailer & Consumer \\
\hline & Coef.(SE) & Coef.(SE) & Coef.(SE) & Coef.(SE) \\
\hline Cons. & $3.89 * * *(1.92)$ & $-0.48(1.27)$ & $-1.58(1.50)$ & $-2.87(1.77)$ \\
\hline Education year & $0.49(0.40)$ & $0.05(-0.52)$ & $-0.01(0.46)$ & $-0.12(0.42)$ \\
\hline Household size & $0.07(0.07)$ & $0.15^{*}(0.08)$ & $0.87^{*}(0.79)$ & $-0.35(0.72)$ \\
\hline Farming experience & $0.13(0.04)$ & $-0.003(0.018)$ & $-0.07(0.17)$ & $-0.03(0.13)$ \\
\hline Volume of mango supplied & $0.01^{*}(0.91)$ & $0.001^{* * *}(0.000)$ & $0.02^{*}(0.01)$ & $-0.07(0.66)$ \\
\hline Quantity of mango produced & $-0.21^{* *}(0.39)$ & $0.124(0.139)$ & $-0.21^{*}(0.12)$ & $-0.97(0.11)$ \\
\hline Price of mango at each outlet & $0.08(0.01)$ & $0.001(0.40)$ & $.01(.11)$ & $0.03^{* *}(0.01)$ \\
\hline Nonfarm income & $0.01^{* * *}(0.00)$ & $0.01^{*}(0.00)$ & $-.03(.00)$ & $-0.04^{* * *}(0.00)$ \\
\hline Number of extension contact & $0.01(0.06)$ & $-0.07(0.09)$ & $.09(.06)$ & $0.03(0.57)$ \\
\hline Access to market information & $-0.47(0.31)$ & $0.06(0.36)$ & $-.656^{*}(.343)$ & $0.43(0.35)$ \\
\hline Distance from nearest market & $0.12^{* * *}(0.05)$ & $-0.28^{*}(0.61)$ & $-.08(.053)$ & $0.63(0.54)$ \\
\hline Having transport facility & $-0.20(0.30)$ & $0.59(-0.36)$ & $-.49(.39)$ & $-0.28(0.32)$ \\
\hline Predicted probability & 0.450 & 0.699 & 0.204 & 0.746 \\
\hline \multicolumn{5}{|c|}{$\begin{array}{l}\text { Joint probability of Success }=0.081 ; \text { Joint Probability of failure }=0.019 \\
\text { Chi2 }(6)=16.89, \text { Prob }>\text { chi } 2=0.0018, \text { Draws }=5\end{array}$} \\
\hline \multicolumn{5}{|l|}{ Number of obs $\quad=195$; } \\
\hline \multicolumn{5}{|l|}{ Wald chi2 (48) = 78.81; } \\
\hline \multicolumn{5}{|l|}{ Log likelihood = -201.61; } \\
\hline \multicolumn{5}{|l|}{ Prob $>$ chi $2=0.0001$} \\
\hline \multicolumn{5}{|c|}{ Likelihood ratio test of rho $21=\operatorname{rho} 31=\operatorname{rho} 41=\operatorname{rho} 32=\operatorname{rho} 42=\operatorname{rho} 43=0:$} \\
\hline \multicolumn{5}{|l|}{ Correlation Matrix } \\
\hline \multicolumn{5}{|l|}{ /atrho21 -.87*.36 } \\
\hline \multicolumn{5}{|l|}{ /atrho31.19.82 } \\
\hline \multicolumn{5}{|l|}{ /atrho41.38.44 } \\
\hline \multicolumn{5}{|l|}{ /atrho32 -.46.65 } \\
\hline \multicolumn{5}{|l|}{ /atrho42 -.15.73 } \\
\hline /atrho43 .91**.38 & & & & \\
\hline
\end{tabular}

Table 3: Determinants of mango market channel choice (Multivariate Probit model result). 
multaneously. The positive coefficient implies that producer tend to increase association with all local collector, wholesaler and retailer to sell their mango product. The other point with this finding reveals that producers those supplies large quantity of mango uses selling for more than one actor as a technique to earn an average price from different outlet channels and to recover their production costs and family expenses.

\section{Household size (HHSIZE)}

This variable positively influenced the likelihood of choosing wholesaler and retailer outlet of producers at $10 \%$ significance level (Table 3). Positive sign shows that household was positively associated with choosing both wholesalers and retailers market outlet due to producers with large household size more likely participates at more than one outlet by using the available of family labor in transporting, cleaning, packaging, producing, storing and selling. This finding is consistent with the finding of Temesgen., et al. [16] who found that having large family size was a better for delivering output to the final outlet.

\section{Conclusion and Recommendation}

The study was conducted in Gambella and Itang Special districts of Gambella Regional state of Ethiopia on specific objectives of Determinants of mango market supply and channel choice with specific objectives of analyzing determinants of mango market outlet choice and volume of mango market supply in study areas. Both qualitative and quantitative types of data were collected from both primary and secondary sources of data through semi- structured questionnaire. Multistage sampling technique was employed to draw sample populations (195 respondents) from 4192 mango producers and by using convenience sampling 10 wholesalers, 12 local collectors, 30 retailers and 3 processors and 20 consumers was interviewed. Both descriptive and econometric models were employed to analyze data's.

Multiple linear regression result indicated that age of household, quantity of mango produced, livestock holding unit, nonfarm income, and distance from the market center were influenced quantity of mango supplied to market at $10 \%, 1 \%, 10 \%$, and $5 \%$ significance level, respectively. The likelihood of choosing local collector was influenced by volume of mango supplied positively, quantity of mango produced negatively, non-farm income positively, and distance from the market center positively at $10 \%, 5 \%$, $1 \%$ and $1 \%$ significance level, respectively. The likelihood of choosing wholesaler market outlet was influenced by household size positively, quantity of mango supplied positively, non-farm income positively, and distance from the market center negatively at $10 \%$, $1 \%, 1 \%$, and $1 \%$ significance level, respectively.

Generally diversifying land uses, using inputs, getting training, making extension contact with agents, using credit, improved seed and new mango variety used to increase productivity of mango which contributes for surplus increment and leads farmers to choose appropriate channel. The financial sector can fund the production of mango products whilst the government can provide subsidized inputs to the small holder farmer. This multispectral ap- proach will definitely yield the required result of increasing income for the smallholder farmer. The government also incorporates technology in the curriculum of institutions of higher learning and research institutes. The private sector can also contract the smallholder farmer by equipping them with the inputs and credit and thus later buy the products to distribute it for the area where this product has shortage.

There is need to reduce over reliance in the preparing of key production inputs. The question that now arises and needs to be addressed in order for the productive farmers to become profitable is do they have the business idea, access to finance, infrastructural support and access to transport and market. One of the most practical solutions to this dilemma is the division of responsibilities between the private sector, Non-government Organizations and government institutions. NGOs can aware farmers through capacity building activities such as farmer group strengthening and business training activities. One aspect of market strategy implementation might be enhancing access to mechanization or other means of enhancing the resource that smallholders have to manage their land use for mango production in order to supply mango product for appropriate and create competitive market.

\section{Bibliography}

1. CSA (Central Statistical Agency). Agricultural Sample Survey 2017/2018. Report on Area and Production of Major Crops. Addis Ababa, Ethiopia 2017/2018.

2. Bezabih Emana. "Market assessment and value chain analysis in Benishangul Gumuz regional state, Ethiopia". Unpublished final report, Addis Ababa (2010).

3. Jifara Teshale and Amsalu Solomon. "Assessment of Cereal Crops (teff, wheat and barley) market constraints in Dandi, Ambo and Toke kutaye districts of Oromia region, Ethiopia". PALGO Journal of Agriculture 4.1 (2017): 225-234.

4. Gujarati DN. Basic Econometrics. 4th Edition. McGraw-Hill, New York. (2003): 563-636.

5. Gambella Peoples National Regional State Districts office of Agriculture and Natural Resoure (DoANR, 2019). Data or information's on characteristics of sample households during (2019).

6. Yamane Taro. Statistics: An Introductory Analysis, 2nd Edition, and New York: Harper and Row (1967).

7. Sultan Usman. "Analysis of wheat value chain: The case of Sinana District, Bale Zone, Oromia Region, Ethiopia”. MSc. Thesis, Haramaya University (2016).

8. Mohammed Urgessa. Market chain analysis of teff and wheat production in Halaba Special Woreda, southern Ethiopia (MSc. Thesis, Haramaya University) (2011). 
9. Azeb Bekele., et al. "Determinants of smallholder farmers in teff market supply in Ambo district, West Shoa Zone of Oromia, Ethiopia". International Journal of Advanced Research in Management and Social Sciences 6 (2017): 133-140.

10. Djalalou-Dine., et al. "Marketing channel selection by smallholder farmers". Journal of Food Products Marketing 21 (2015): 337-357.

11. Addisu Hailu. Value chain analysis of vegetables: the case of Ejere District, West Shoa Zone, Oromia National Regional State of Ethiopia (MSc. Thesis, Haramaya University) (2016).

12. Greene W. Econometric analysis, 7th end. Prentice Hall, Pearson, NJ. (2012).

13. Shewaye Abera., et al. "Econometric analysis of factors affecting haricot bean market outlet choices in MisrakBadawacho District, Ethiopia”. International Journal of Research Studies in Agricultural Sciences 2 (2016): 6-12.

14. Oliyad Sori., et al. "Factors Affecting Market Outlet Choice of Groundnut Producers in Digga District of Oromia State, Ethiopia”. Journal of Economics and Sustainable Development 8 (2017): 61-68.

15. Cappellarri L and Jenkins SP. "Multivariate probit regression using simulated maximum likelihood". The Stata Journal 3 (2003): 278-294.

16. Temesgen Kabeta., et al. "Value Chain Analysis of Teff: The case of Jimma Arjo district east Wollega zone of western Ethiopia. MSc. Thesis submitted to Jimma University (2018).

17. Addisu Tefera. "Determinants of Commercialization and Market outlet choices of Teff: The Case of Smallholder Farmers in Dendi district of Oromia, Central Ethiopia”. MSc. Thesis, Haramaya University, Haramaya, Ethiopia (2018).

\section{Volume 3 Issue 12 December 2019}

(C) All rights are reserved by Temesgen Kabeta and Jemberu Alemu. 